\title{
sciendo
}

Folia Oeconomica Stetinensia

Volume 18 (2018) Issue 1

DOI: $10.2478 /$ foli-2018-0004
WYDZIAL NAUK EKONOMICZNYCH I ZARZA_DZANIA

\section{GEOGRAPHICAL DIVERSIFICATION OF GMINA REVENUE FROM REAL ESTATE MARKET IN POLAND}

\author{
Joanna Cymerman, Ph.D. \\ Koszalin University of Technology \\ Faculty of Civil Engineering, Environmental and Geodetics Sciences \\ Departament of Geoinformatics \\ Office of Real Estate Management and Real Estate Cadastre \\ Śniadeckich 2, 75-453 Koszalin, Poland \\ e-mail: joanna.cymerman@wilsig.tu.koszalin.pl
}

Wojciech Cymerman, Ph.D.

University of Live Sciences in Lublin

Faculty of Production Engineering

Departament of Geodesy and Spatial Information

Glęboka 28, 20-612 Lublin, Poland

e-mail:wojtekc@uwm.edu.pl

Received 19 November 2017, Accepted 25 March 2018

\begin{abstract}
The paper discusses the local government revenue from the real estate market, focusing mainly on identifying the spatial differentiation of municipal income from the real estate market. The study covered all communes (gminas) in Poland $(2,478)$. The temporal scope of the study was a decade between 2005 and 2015. The analyses focused on the following three groups of revenue from a real estate market: recurrent property taxes, revenue from municipal assets, and taxes in respect of the ownership right transfer. The main research hypothesis was made that the community located in central and north-western Poland gain higher income from the real estate market, than other gminas. The analyses were carried out on the basis of particular types of gminas (municipalities, urban-rural communities, and rural communities - in the voivodeship arrangement). Voivodeship capitals were subjected to separate analyses because of the specific central character of their public functions. The data came from the Local Data Bank of the Polish Central Statistical Office. The data analysis was conducted by means of statistical and econometric methods.
\end{abstract}

Keywords: gmina, real estate market, public revenue

JEL classification: $H 70$, R30 


\section{Introduction}

In the modern world, the real estate market plays a vital role in the development management of individual countries and territorial systems. It results from the fact that real property is a capital which enables its owner to create positive effects not only for themselves but also for local and national stakeholders (Ball, Lizieri, MacGregor, 1998; Pęski, 1999; Markowski 1999; Domański, 2007). A particularly strong relationship occurs between the real estate market and the economy - on the one hand, the phenomena and processes taking place in the economy may stimulate or hinder the development of this market by changing the demand for space, the interest rates, or the attractivenes of other capital investments. On the other hand, the real estate market affects macroeconomic variables through participating in the GDP creation, creating new jobs, providing an opportunity to unfreeze capital, or generating tax revenue (Case, 2000; Wiśniewska, 2004; Kucharska-Stasiak, 2016). In 2015, the Polish real estate market fed local budgets with 31,762 million zloty, which accounted for $35.26 \%$ of the local governments' own income and meant a 70.5\% leap in comparison to 2005. In the decade of 2006-2015, the gmina revenues were gradually increasing at an average annual rate of $5.57 \%$, with two exceptions of 2015 with a marginal fall by $0.59 \%$ and 2009 with a more notable fall in revenue YOY at $1.23 \%$. The gmina revenue from the real estate market is determined by several factors (both endoand exogenous) of a diverse character, such as resource size and location, legal and political, economic and social. Some of them, of objective nature, are independent from local authorities (gmina size, character and the rate of urbanisation, its location and function within the national settlement pattern, etc.). Yet, there is also a group of factors that are dependent on the local government, in particular the gmina's development policy, land use policy, real property policy as well as its tax policy (Kisiała, Trojanek, 2017). In this respect, gminas function within two spheres: public and public-private. In the former sphere, they operate from the superior position (imperium) as a local host who steers the local development and manages land use and tax policies. In the latter case, the gmina acts as equal (dominium) - being an entity in the municipal property resource that creates supply and demand on the local real estate market.

The above correlation was the rationale behind this study which was aimed at identifying the spatial differentiation of municipal income from the real estate market. The study covered all communes in Poland (2478). The temporal scope of the analysis was a decade between 2005 and 2015. The analyses focused on the following three groups of revenue from the real estate market: recurrent property taxes, revenue from municipal assets, and taxes in respect of ownership right transfer. The main research hypothesis was made that the community located in central 
and north-western Poland gain higher income from the real estate market than other gminas. The analyses were carried out on the basis of the particular types of gminas (municipalities, urban-rural communities, and rural communities in the voivodeship arrangement). Voivodeship capitals were subjected to separate analyses because of the particular central character of their public functions. The data came from the Local Data Bank of the Polish Central Statistical Office. The data analysis was conducted by means of statistical and econometric methods.

\section{Gmina Revenue from Real Estate Market and its Determinants}

The provisions of the Polish Constitution (Konstytucja..., 1997, Articles 165, 167, 168) guarantee to gminas their legal (legal personality, the right to own municipal property), organizational (freedom in executing public functions in their own name and under their own responsibility), and financial autonomy (their share in public revenues, right to set their own rates of local taxes and charges). The primary act of law regulating the Polish local governments' sources of income is the Act on income of local government units of 13 November 2003 (Journal of Laws 2017, item 1453 as amended). The Polish gmina revenue system, similarly to its EU counterparts, is mixed, which means that it is based on gminas' own revenue (coming mainly from local charges and taxes and their own assets) as well as on the funds transferred from the state budget in the form of general subsidies, targeted subsidies, and a share in personal and corporate income taxes (Gliniecka, 2001). A considerable part of the gminas' own revenue is represented by the income from the real estate market that falls into five categories (Cymerman, 2011; Głuszczak, Marona, 2015):

a) recurrent property taxes - property taxes related to ownership rights but unrelated with any economic event or adminstrative-law procedure (property, agricultural, or forestry taxes);

b) revenue from municipal assets - civil-law charges collected on account of a property sale or lease (income from property sale, letting, leasing, or perpetual usufruct);

c) taxes in respect of ownership right transfer payable when transfering property rights in a form of market and non-market transactions (civil-law action tax, inheritance, and gift tax);

d) income taxes levied on the income from property sale, letting, leasing, etc. (personal income tax and corporate income tax); 
e) charges levied on an increased property value due to a local government activity changes in the local land use plan (planning fees), land division, reparcelling, upgrading (impact fees).

The gmina revenue from the real estate market is determined by several factors (both endo- and exogenous) of a diverse character, such as resource- and location-related, legal and political, economic and social (Figure 1).
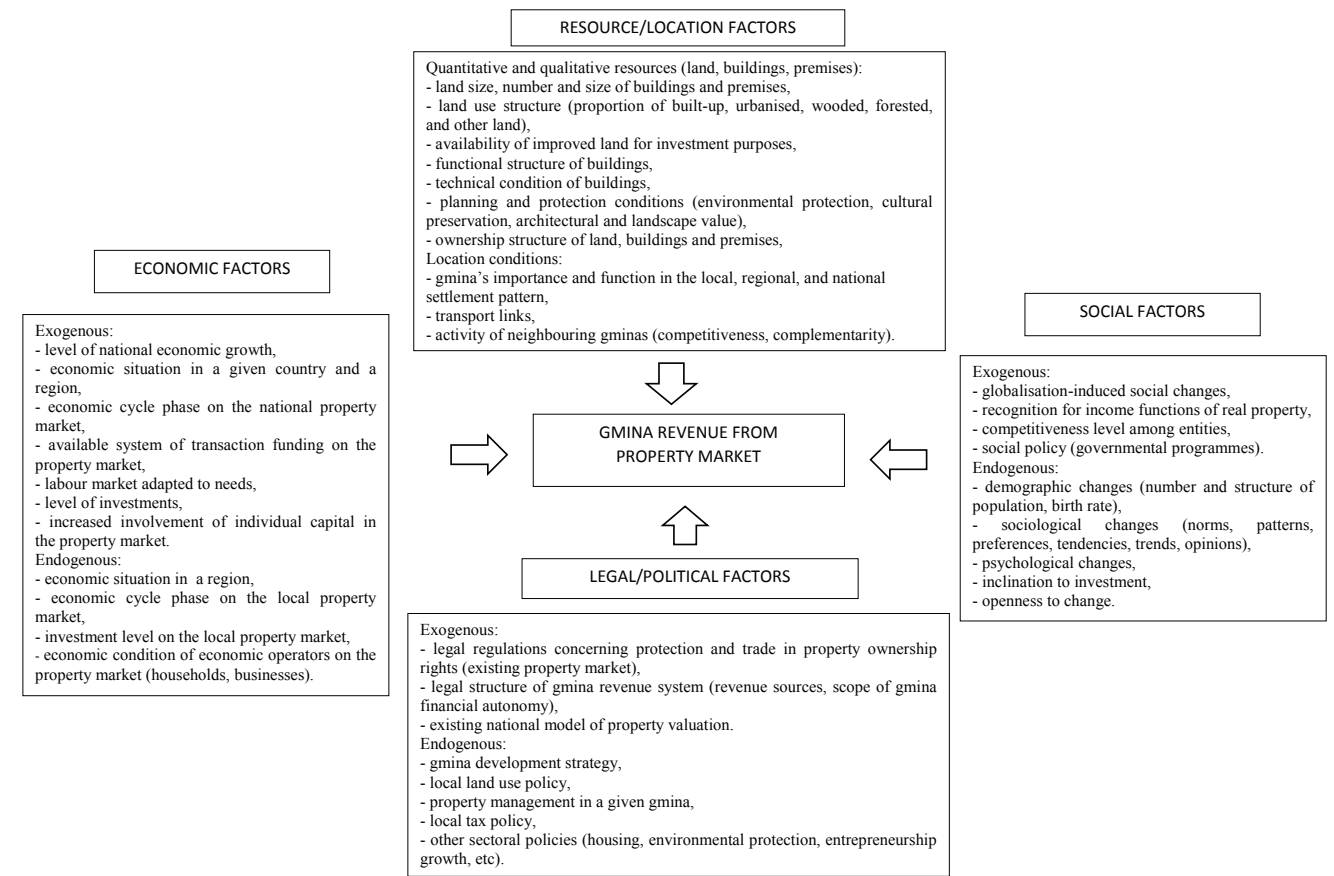

Figure 1. Determinants of the gminas revenue from the real estate market

Source: authors' own study.

The resource- and location-related factors are associated with the size and quality of the property stock traded on the local real estate market as well as with the gmina geographical conditions (Markowski, 1999; Domański, 2007). These are in particular: the total area of land, the number and floor area of buildings and premises, the land use structure (the proportion of developed and urbanised, agricultural and wooded land), the functional structure and technical condition of buildings, the planning and protection regulations (environmental protection, cultural heritage protection), the ownership structure of the resource, and the powers and functions of gmina in the local, regional, and national settlement structure. 
The legal and political factors include the ones of the exogeneous character that encompass legal regulations concerning the protection and turnover of ownership rights which are fundamental for the real estate market, as well as the legal structure of the gmina resource system that defines their income sources (Patrzałek, 2004; Chojna-Duch, 2017), the limits of their financial autonomy, and the national model of property valuation. The endogenous factors contain the local authorities' land use and real estate management policies, local tax policy, and other sector policies (housing, entrepreneurship growth, etc.) resulting from the gmina development strategy.

The economic factors include the level of economic development and the economic cycle phase in a given country or region as well as on the domestic and local real estate market (Bartle, Kriz, Morozov, 2011), the available system of financing real estate transactions, the investment volume, and the economic performance of the actors on the real estate markets (such as households and companies).

The last group are social factors of exogenous (globalisation-related social changes, the perception of the income functions of the real estate or social policy) and endogenous (demographic changes such as the number and structure of population, birth rate, sociological and psychological changes) nature.

\section{Analyses results}

The analyses covered the revenue from the real estatemarket in all gminas in Poland (2,478), including: 16 voivodeship cities, ${ }^{1} 288$ municipalities, 611 urban-rural communities, and 1,563 rural communities, between 2005 and 2015. The main research hypothesis was made that the community located in central and north-western Poland gain higher income from the real estate market than other gminas. The analyses were carried out on the basis of the particular types of gminas (voivodeship cities, municipalities, urban-rural communities, and rural communities - in the voivodeship arrangement). The data came from the Local Data Bank of the Polish Central Statistical Office. The analyses focused on the following three groups of revenue from the real estate market:

a) recurrent property taxes - a property tax, an agricultural tax, and a forestry tax;

b) revenue from municipal assets - the income from property sale, letting, leasing, and from perpetual usufruct);

\footnotetext{
1 Voivodship capitals were subjected to separate analyzes because of the particular central character of their public functions.
} 
c) taxes in respect of ownership right transfer - a civil-law action tax, an inheritance, and a gift tax).

The revenue from the income tax related to the real estate market was excluded from the analysis due to the absence of relevant data - the part of income taxes levied on the gains from the sale, rental, and lease of properties is not separated from the total envelope of income taxes in the Tax Office records. Additionally, the analysis did not include the gains from the charges in respect of the increased property value due to their marginal importance as they do not exceed $1 \%$ of the cities' own revenue.

Over the decade of 2005-2015, the gminas' revenue from the real estate market totalled PLN 285.841 billion, of which voivodeship capitals accounted for $28.9 \%$, urban gminas - for $31.9 \%$, urban-rural gminas - for $19.4 \%$, and rural gminas - for $19.8 \%$. In 2015 , the gmina revenue from the real estate market reached PLN 32.051 billion, representing an increase of $70.5 \%$ as compared to 2005 . In the period covered by the analysis, the gmina revenue from the real estate market grew at the annual average of 5.7\%, with the exception of 2015 when it fell marginally by $0.1 \%$, and of 2009 with a more notable decrease of $1.08 \%$ YOY (Figure 2 ).

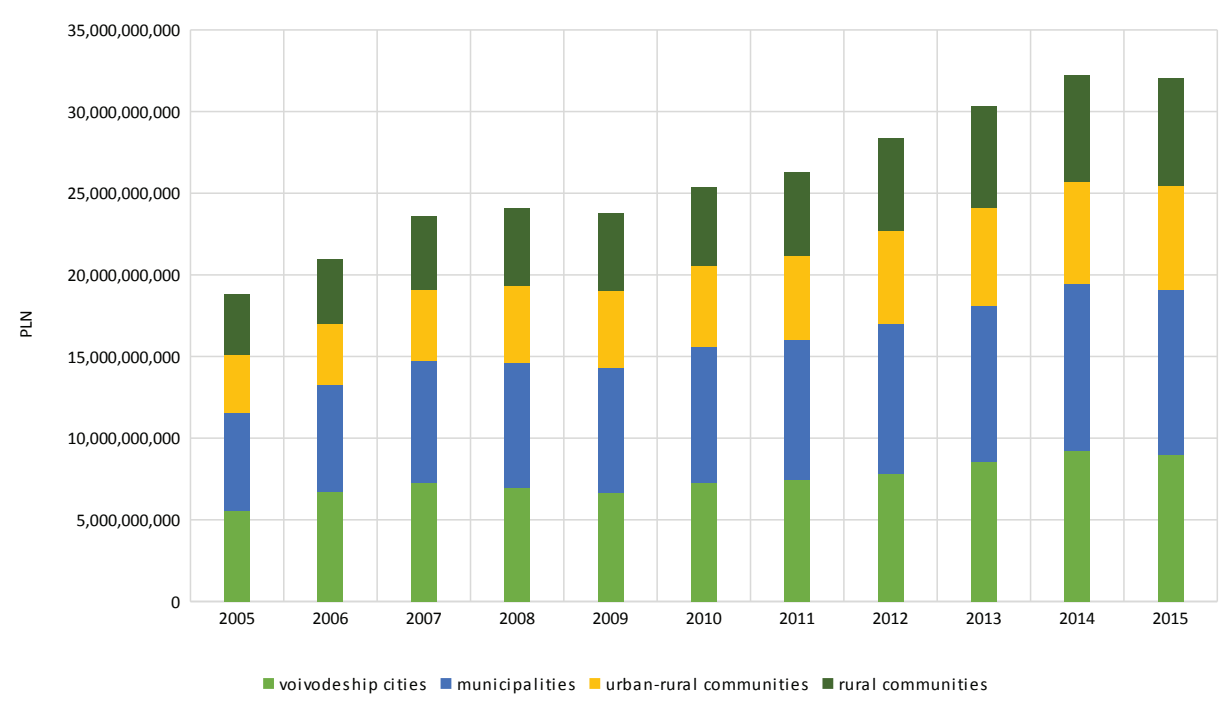

Figure 2. Revenue from the real estate market in gminas over 2005-2015

Source: authors' own study based on GUS Local Data Bank of Central Statistical Office.

Starting from 2007, in voivodeship capitals, the growth dynamics of the revenue from the real estate market was considerably higher than in other types of gminas (Figure 3). In 2008, 
the voivodeship capitals saw a clear slow down of the revenue growth dynamics, while in the remaining gmina types the upward trend was maintained.

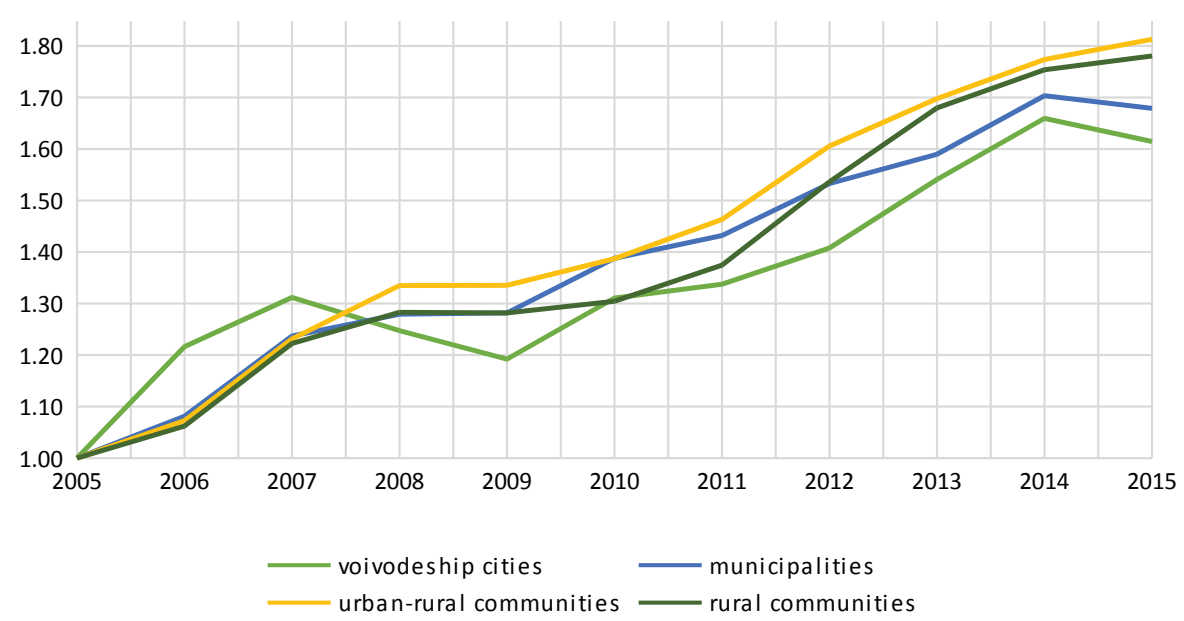

Figure 3. Fixed bases of the revenue from the real estate market in gminas $(2005=100)$ Source: authors' own study based on GUS Local Data Bank of Central Statistical Office.

In 2009, the aggravation of downward trends in voivodeship capitals was seen, while in the other types of gminas, the upward movement slowed down. In the following years, there was a clear increase in the dynamics of gmina revenue from the real estate market, the most intense being in the urban-rural gminas and, which is quite interesting, the slowest - in the voivodeship capitals. However, in 2015, the upward trend decelerated in urban gminas and in the voivodeship capitals. In the period covered by the analysis, the highest growth of gmina revenue took place in the urban-rural gminas (an increase by $81.28 \%$ as compared to 2005 ) and the lowest in the voivodeship capitals (by 61.44\%).

The major source of gmina revenue from the real estate market was the property tax which accounted on average for $64.34 \%$ of this part of gmina budgets (the highest being in urbanrural gminas at $67.77 \%$, and the lowest - in voivodeship capitals at $58.03 \%$ ). The second most important revenue source was municipal assets that accounted for the average of $20.64 \%$ of the gmina revenue from the real estate market (ranging from $28.32 \%$ in the voivodeship capitals to $11.76 \%$ in the rural gminas) (Figure 4). The third largest source of gmina revenue from the real estate market in the voivodeship capitals and urban gminas was the civil-law action tax, while in the urban-rural and rural gminas, it was the agricultural tax. The least relevant for gmina budgets was the revenue from the forestry tax $(0.93 \%$ on average $)$. 


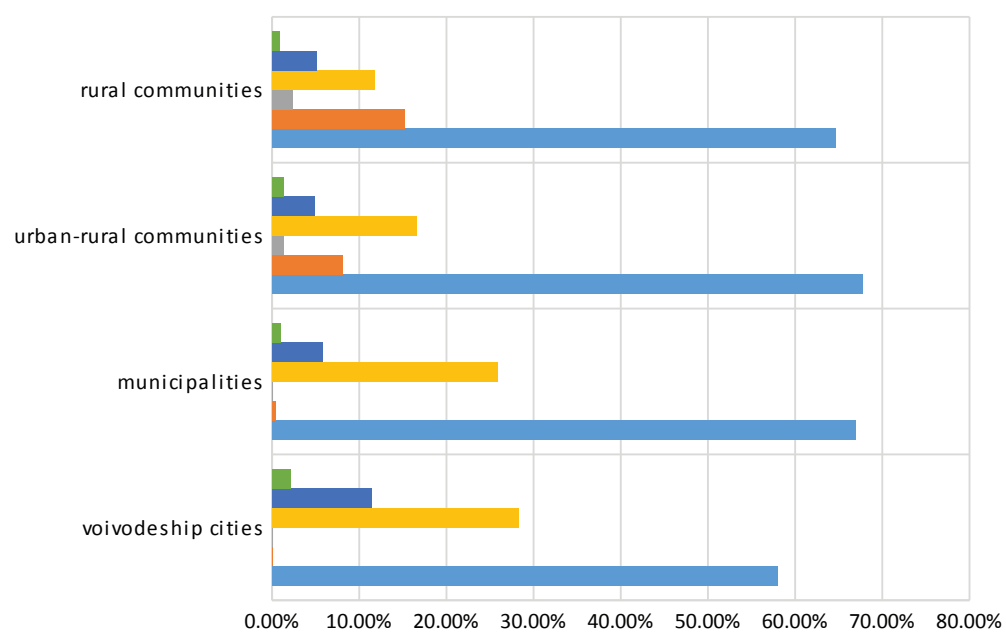

Figure 4. The structure of the revenue from the real estate market in gminas in 2005-2015 Source: authors' own study based on GUS Local Data Bank of Central Statistical Office.

The highest revenue per capita from the real estate market was seen in the voivodeship capitals (at the annual average of PLN 864.09, followed by PLN 691.88 in the urban gminas, PLN 561.57 in the urban-rural gminas, and PLN 522.50 in the rural ones). The widest internal diversity was in the group of the rural gminas in West Pomeranian Voivodeship, where the revenue per capita from the property market (PLN 900.84) was $178 \%$ higher than in Lubusz Voivodeship with PLN 323.92. The least diversified were the urban gminas (Table 1).

Table 1. Per capita revenue from the real estate market in gminas (PLN)

- descriptive characteristics

\begin{tabular}{|l|c|c|c|c|}
\cline { 2 - 5 } \multicolumn{1}{c|}{} & Voivodeship-cities & Municipalities & Urban-rural communities & Rural communities \\
\hline Minimum & 649.76 & 534.56 & 390.17 & 323.92 \\
\hline Maximum & $1,363.57$ & 951.95 & 812.85 & 900.84 \\
\hline Arithmetic average & 864.09 & 691.88 & 561.57 & 522.50 \\
\hline Median & 776.99 & 691.56 & 558.00 & 527.82 \\
\hline Standard deviation & 233.09 & 105.20 & 121.35 & 174.32 \\
\hline
\end{tabular}

Source: authors' own study.

The highest revenue per capita from the real estate market was reported in Warsaw (PLN 1,394.52) and Wrocław (PLN 1,363.57), being significantly different from other gminas. The third was Opole (PLN 1,004.17) closely followed by Gdańsk, Katowice, the urban gminas in Opole Voivodeship, and the rural gminas of West Pomeranian Voivodeship (Table 2). 
Table 2. Distribution of gminas by per capita revenue from the real estate market

\begin{tabular}{|c|c|c|c|c|}
\hline $\begin{array}{c}\text { Per capita revenue } \\
\text { from real estate } \\
\text { market }\end{array}$ & Voivodeship cities & Municipalities & $\begin{array}{l}\text { Urban-rural } \\
\text { communities }\end{array}$ & Rural communities \\
\hline 1,301-1,400 PLN & Warsaw, Wrocław & - & - & - \\
\hline 1,201-1,300 PLN & - & - & - & - \\
\hline $1,101-1,200$ PLN & - & - & - & - \\
\hline $1,001-1,100$ PLN & Opole & - & - & - \\
\hline 901-1,000 PLN & Gdańsk, Katowice & Opole & - & West Pomeranian \\
\hline 801-900 PLN & $\begin{array}{c}\text { Kraków, Poznań, } \\
\text { Białystok }\end{array}$ & Pomeranian & West Pomeranian & - \\
\hline 701-800 PLN & $\begin{array}{l}\text { Łódź, Kielce, } \\
\text { Szczecin, Rzeszów }\end{array}$ & $\begin{array}{l}\text { Lower Silesian, Kuyavian- } \\
\text { Pomeranian, Silesian, } \\
\text { Lesser Poland, } \\
\text { West Pomeranian, Lubusz }\end{array}$ & Lower Silesian & Lower Silesian \\
\hline 601-700 PLN & $\begin{array}{l}\text { Olsztyn, Bydgoszcz, } \\
\text { Zielona Góra, Lublin }\end{array}$ & $\begin{array}{l}\text { Podlaskie, Masovian, } \\
\text { Podkarpackie, Greater } \\
\text { Poland, Świętokrzyskie }\end{array}$ & $\begin{array}{l}\text { Lubusz, } \\
\text { Opole, Masovian }\end{array}$ & $\begin{array}{c}\text { Pomeranian, Opole, } \\
\text { Lubusz }\end{array}$ \\
\hline 501-600 PLN & - & $\begin{array}{l}\text { Łódź, Warmian-Masurian, } \\
\text { Lublin }\end{array}$ & $\begin{array}{l}\text { Greater Poland, } \\
\text { Kuyavian- } \\
\text { Pomeranian, } \\
\text { Warmian- } \\
\text { Masurian, } \\
\text { Łódź, Silesian, } \\
\text { Pomeranian }\end{array}$ & $\begin{array}{l}\text { Łódź, Warmian- } \\
\text { Masurian, Greater } \\
\text { Poland }\end{array}$ \\
\hline 401-500 PLN & - & - & $\begin{array}{l}\text { Świętokrzyskie, } \\
\text { Podlaskie, Lesser } \\
\text { Poland }\end{array}$ & $\begin{array}{c}\text { Podlaskie, } \\
\text { Kuyavian- } \\
\text { Pomeranian, } \\
\text { Masovian, Silesian }\end{array}$ \\
\hline 301-400 PLN & - & - & $\begin{array}{l}\text { Podkarpackie, } \\
\text { Lublin }\end{array}$ & $\begin{array}{l}\text { Podkarpackie, } \\
\text { Lublin, } \\
\text { Świętokrzyskie }\end{array}$ \\
\hline 201-300 PLN & - & - & - & Lesser Poland \\
\hline
\end{tabular}

Source: authors' own study.

It can be seen that the empirical distribution of the average annual gmina revenue from the real estate market in the period of this analysis has the characteristics of the normal distribution with the expected value at PLN 660 and the standard deviation at PLN 209 (Figure 5).

When analysing the geographical diversity of the gmina revenues from the real estate market, it can be seen that the gminas in the voivodeships in North and North-west Poland obtained much higher revenue than in South and South-east Poland (Figure 6).

In the period covered by the analysis, the revenue from the real estate market played the most important role in the budgets of the rural and urban-rural gminas, accounting for $46.87 \%$ and $46.14 \%$ of the gminas' own revenue respectively. They played the least important part in the budgets of the voivodeship capitals, where they constituted less than one third of the gminas' own income (Table 3). 


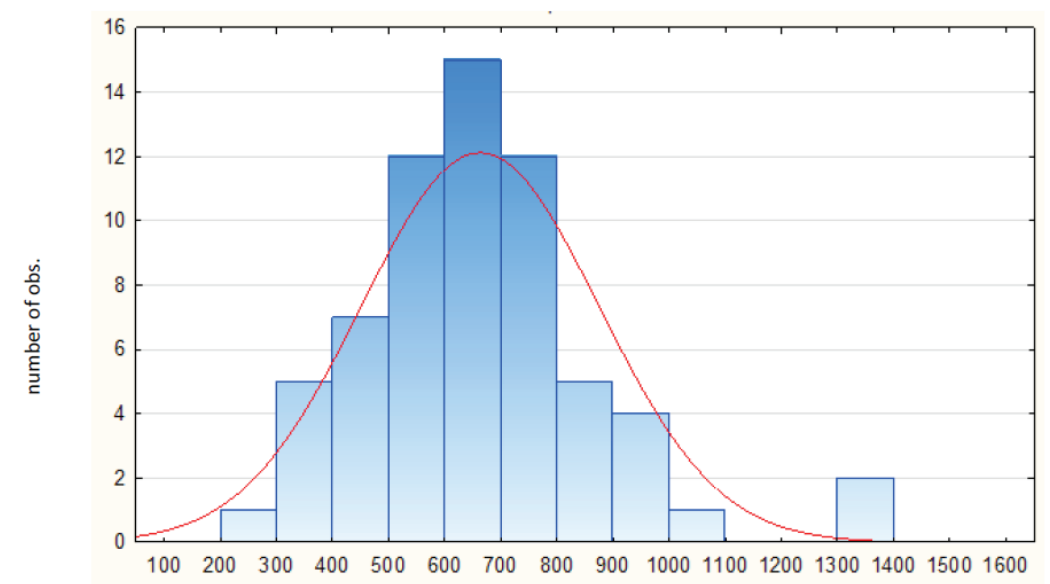

per capita revenue from real estate market (PLN)

Figure 5. Histogram of the distribution by per capita revenue from the real estate market in the gminas (PLN)

Source: authors' own study.

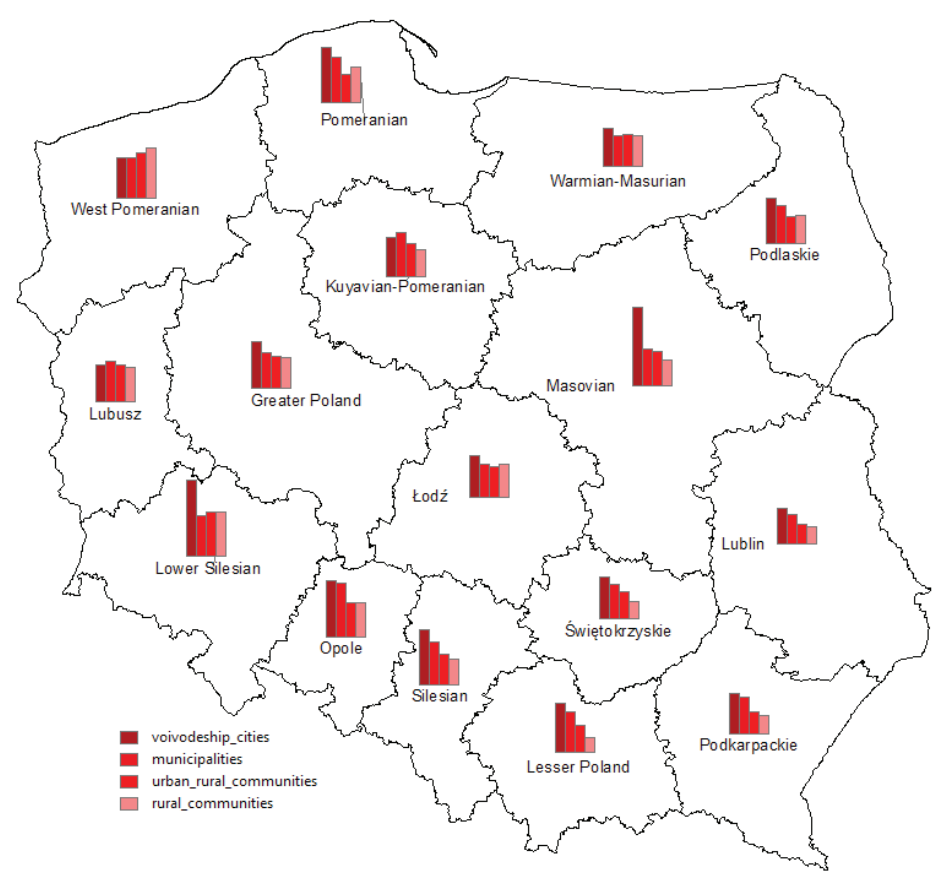

Figure 6. Per capita revenue from the real estate market in gminas over 2005-2015 (PLN)

Source: authors' own study based on GUS Local Data Bank of Central Statistical Office. 
Table 3. Percentage of the revenue from the real estate market in the gminas' own revenues - descriptive characteristics

\begin{tabular}{|l|c|c|c|c|}
\cline { 2 - 4 } \multicolumn{1}{c|}{} & Voivodeship cities & Municipalities & $\begin{array}{c}\text { Urban-rural } \\
\text { communities }\end{array}$ & Rural communities \\
\hline Minimum & 27.54 & 32.19 & 36.85 & 35.30 \\
\hline Maximum & 38.71 & 52.96 & 53.81 & 55.70 \\
\hline Arithmetic average & 32.57 & 39.75 & 46.14 & 46.87 \\
\hline Median & 32.17 & 39.14 & 46.19 & 46.94 \\
\hline Standard deviation & 3.22 & 4.57 & 4.50 & 6.49 \\
\hline
\end{tabular}

Source: authors' own study.

When analysing the geographical diversity, it is clear that the revenue from the real estate market constitutes the most important part in the budgets of the gminas in West and North-west Poland in contrast to the gminas in South Poland where the situation is reverse (Figure 7).

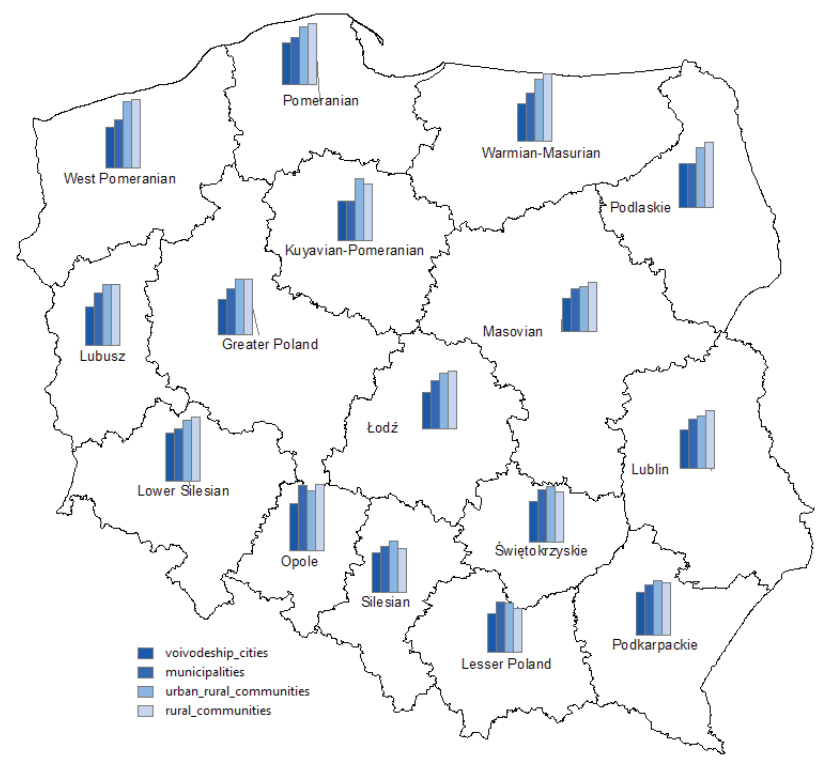

Figure 7. Percentage of the revenue from the real estate market in the gminas' own revenues Source: authors'own study based on GUS Local Data Bank of Central Statistical Office.

For the purpose of the research hypothesis verification, the voivodeship capitals as well as the urban, urban-rural, and rural gminas were analysed by the voivodeships in terms of their revenues obtained from the real estate market. The analysis used seven diagnostic variables being average annual values for the period of the analysis: 
a) per capita revenue from recurrent property taxes in PLN,

b) per capita revenue from municipal assets in PLN,

c) per capita revenue from taxes in respect of ownership right transfer in PLN,

d) average annual growth rate of per capita revenue from recurrent property taxes,

e) average annual growth rate of per capita revenue from municipal assets,

f) average annual growth rate of per capita revenue from taxes in respect of ownership right transfer,

g) ratio of the revenue from the real estate market to the gmina's own revenue.

Basing on the obtained variable values, the voivodeship capitals and the urban, urbanrural, and rural gminas were ranked from the highest first position (16 points) to the lowest $16^{\text {th }}$ (1 point). The maximum number of points to be scored in the ranking was $112(100 \%)$. The results of the ranking are shown in Figure 8 and in Table 4.

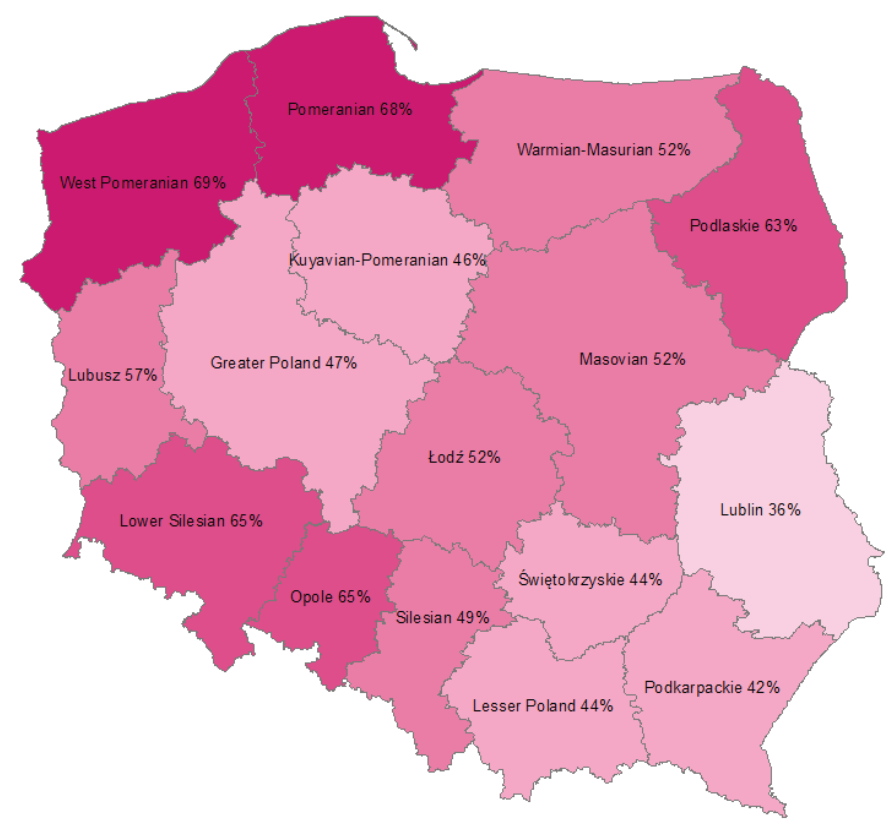

Figure 8. Evaluation of the gminas in the aspect of the income from the real estate market in 2005-2015 - in the voivodeship arrangement

Source: authors' own study.

At the top positions in the ranking, there were gminas from North-west and South-west Poland, i.e. from West Pomeranian (ranked $\left.1^{\text {st }}\right)$, Pomeranian $\left(2^{\text {nd }}\right)$, Opole $\left(3^{\text {rd }}\right)$, and Lower SilesianVoivodeship $\left(4^{\text {th }}\right)$. The lowest positions were taken by the gminas from South-east Poland: 
Table 4. Ranking of the gminas according to their income from the real estate market in 2005-2015 - in the voivodeship arrangement

\begin{tabular}{|c|c|c|c|c|c|c|c|c|c|c|c|}
\hline & \multirow[b]{2}{*}{ Voivodeship } & \multicolumn{2}{|c|}{$\begin{array}{c}\text { Voivodeship } \\
\text { cities }\end{array}$} & \multicolumn{2}{|c|}{ Municipalities } & \multicolumn{2}{|c|}{$\begin{array}{c}\text { Urban-rural } \\
\text { communities }\end{array}$} & \multicolumn{2}{|c|}{$\begin{array}{c}\text { Rural } \\
\text { communities }\end{array}$} & \multicolumn{2}{|c|}{$\begin{array}{l}\text { All types } \\
\text { of gminas }\end{array}$} \\
\hline & & 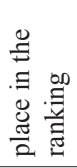 & 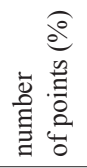 & 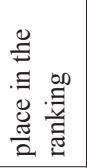 & 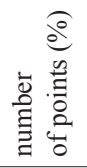 & 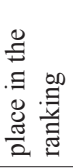 & 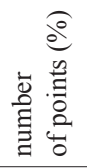 & 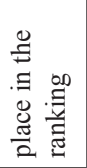 & 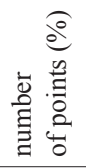 & 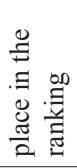 & 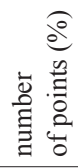 \\
\hline 1 & West Pomeranian & 8 & 52.68 & 1 & 74.11 & 5 & 63.39 & 1 & 86.61 & 1 & 69.20 \\
\hline 2 & Pomeranian & 1 & 74.11 & 5 & 63.39 & 2 & 67.86 & 5 & 66.07 & 2 & 67.86 \\
\hline 3 & Opole & 4 & 69.64 & 2 & 66.07 & 9 & 51.79 & 2 & 72.32 & 3 & 64.96 \\
\hline 4 & Lower Siles & 3 & 70.54 & 9 & 51.79 & 1 & 71.43 & 6 & 64.29 & 4 & 64.51 \\
\hline 5 & Podlaskie & 5 & 64.29 & 4 & 64.29 & 7 & 61.61 & 7 & 62.50 & 5 & 63.17 \\
\hline 6 & Lubusz & 16 & 27.68 & 3 & 64.29 & 3 & 66.07 & 3 & 71.43 & 6 & 57.37 \\
\hline 7 & Masovian & 6 & 55.36 & 11 & 50.00 & 11 & 45.54 & 8 & 58.04 & 7 & 52.23 \\
\hline 8 & Łódź & 10 & 50.00 & 12 & 45.54 & 4 & 64.29 & 10 & 46.43 & 8 & 51.56 \\
\hline 9 & Warmian-Masurian & 14 & 41.07 & 14 & 37.50 & 8 & 59.82 & 4 & 67.86 & 9 & 51.56 \\
\hline 10 & Silesian & 2 & 71.43 & 8 & 55.36 & 13 & 41.96 & 16 & 27.68 & 10 & 49.11 \\
\hline 11 & Greater Poland & 7 & 53.57 & 15 & 35.71 & 10 & 48.21 & 9 & 51.79 & 11 & 47.32 \\
\hline 12 & Kuyavian-Pomeranian & 15 & 31.25 & 7 & 55.36 & 6 & 61.61 & 13 & 34.82 & 12 & 45.76 \\
\hline 13 & Świętokrzyskie & 13 & 44.64 & 10 & 51.79 & 12 & 43.75 & 12 & 37.50 & 13 & 44.42 \\
\hline 14 & Lesser Poland & 12 & 44.64 & 6 & 58.04 & 16 & 31.25 & 11 & 40.18 & 14 & 43.53 \\
\hline 15 & Podkarpackie & 9 & 51.79 & 13 & 41.96 & 14 & 38.39 & 14 & 33.93 & 15 & 41.52 \\
\hline 16 & Lublin & 11 & 47.32 & 16 & 34.82 & 15 & 33.04 & 15 & 28.57 & 16 & 35.94 \\
\hline
\end{tabular}

Source: authors' own study.

Lublin $\left(16^{\text {th }}\right)$, Podkarpackie $\left(15^{\text {th }}\right)$, Lesser Poland $\left(14^{\text {th }}\right)$, and Świętokrzyskie Voivodeship $\left(13^{\text {th }}\right) .^{2}$ The obtained results of the analyses should be interpreted taking into account the diversity of the local determinants of commune income from the real estate market, mainly: resourceand location-related, economic, and political. The gminas located in the North-west Poland are characterized by a good location, close to the Sea, which translates into interest in the real estate market by potential investors. The gminas located in the South-west Poland have a good geopolitical location - they are close and with a good communication to the capitals of two European countries, Berlin and Prague. The gminas located in the South-east Poland have worse locational-resource and economic conditions.

\footnotetext{
${ }^{2}$ However, it should be noted that there are differences between the particular types of municipalities.
} 


\section{Conclusions}

The analyses have shown that in the period between 2005 and 2015, the gmina revenues from the real estate market were geographically diversified. The research hypothesis has been partially verified - it is true only in reference to the gminas in the voivodeships of North-west and North Poland whose revenue from the real estate market were higher. The gminas located in central Poland, i.e. in Masovian, Greater Poland, and Łódź Voivodeship, were ranked as the $7^{\text {th }}, 11^{\text {th }}$, and $8^{\text {th }}$, respectively. It would be necessary to deepen the analysis of the types of income conditions for the gminas from the real estate market. It requires determining which of them have a greater impact on the amount of income, and which of them (endogenous) are more influenced by municipalities.

\section{References}

Ball, M., Lizieri, C., MacGregor, B.D. (1998). The Economics of Commercial Property Markets. London, New York: Routledge.

Bartle, J.R., Kriz, K.A., Morozov, B. (2011). Local government revenue structure: trends and challenges. Journal of Public Budgeting, Accounting \& Financial Management, 23 (2), 268-287.

Case, C.E. (2000). Real Estate and Macroeconomy. Brookings Papers on Economic Activity, 2.

Chojna-Duch, E. (2017). Prawo finansowe. Finanse publiczne. Warszawa: Oficyna Prawa Polskiego.

Cymerman, J. (2011). Aktywna gospodarka nieruchomościami w gminie. Prawo. Instrumenty. Dochody gmin. Koszalin: Wydawnictwo Uczelniane Politechniki Koszalińskiej.

Domański, R. (2007). Gospodarka przestrzenna Podstawy teoretyczne. Warszawa: Wydawnictwo Naukowe PWN.

Gliniecka, J. (2001). Zasady polskiego prawa dochodów samorządu terytorialnego. Bydgoszcz: Wydawnictwo Branta.

Głuszak, M., Marona, B. (2015). Podatek katastralny. Ekonomiczne uwarunkowania reformy opodatkowania nieruchomości. Warszawa: Wydawnictwo Poltex.

Kisiała, W., Trojanek M. (2017). Typologia gmin w Polsce na podstawie dochodów z nieruchomości. Acta Sci. Pol., Administratio Locorum, 16 (2), 77-85.

Konstytucja Rzeczypospolitej Polskiej z 2 kwietnia 1997 r. (Dz.U. nr 78, poz. 483). 
Kucharska-Stasiak, E. (2016). Ekonomiczny wymiar nieruchomości. Warszawa: Wydawnictwo Naukowe PWN.

Markowski, T. (1999). Zarządzanie rozwojem miast. Warszawa: Wydawnictwo Naukowe PWN.

Patrzałek, L. (2004). Finanse samorzadu terytorialnego. Wrocław: Wydawnictwo Akademii Ekonomicznej we Wrocławiu.

Pęski, W. (1999). Zarządzanie rozwojem zrównoważonym. Warszawa: Wydawnictwo Arkady.

Wiśniewska, E. (2004). Rynek nieruchomości a gospodarka. In: E. Kucharska-Stasiak (ed.), Zachodnie rynki nieruchomości. Warszawa: Twigger. 